Social Sciences on Contemporary Turkey

3 | 2005

THEMATIC ISSUE

Being a MP in contemporary Turkey

\title{
Being a Member of Parliament in contemporary Turkey
}

Gilles Dorronsoro and Élise Massicard

\section{(2) OpenEdition \\ Journals}

Electronic version

URL: http://journals.openedition.org/ejts/502

DOI: $10.4000 /$ ejts.502

ISSN: $1773-0546$

Publisher

EJTS

Electronic reference

Gilles Dorronsoro and Élise Massicard, "Being a Member of Parliament in contemporary Turkey », European Journal of Turkish Studies [Online], 3 | 2005, Online since 04 March 2015, connection on 16 February 2020. URL : http://journals.openedition.org/ejts/502 ; DOI : 10.4000/ejts.502 


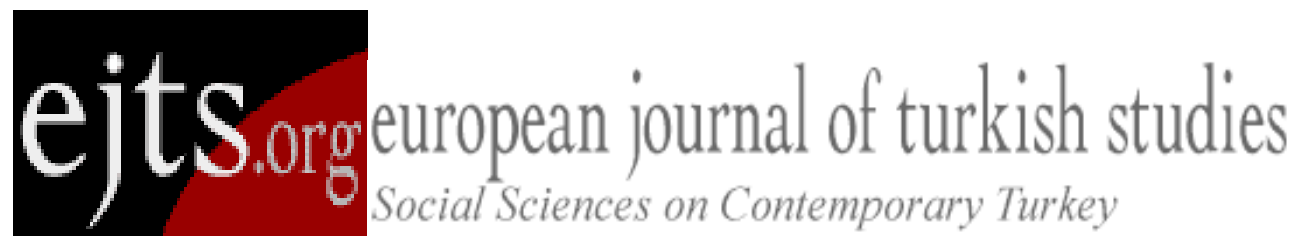

Citation: Dorronsoro, Gilles and Massicard, Elise (2005) 'Being a Member of Parliament in contemporary Turkey', European Journal of Turkish Studies, Thematic Issue N³, Being a MP in contemporary Turkey, URL: http://www.eits.org/document502.html

To quote a passage, use paragraph (§).

\section{Being a Member of Parliament in contemporary Turkey}

Gilles Dorronsoro

Elise Massicard

\section{Introduction}

The MP's position in the Turkish political system: central, but dominated

Since the end of the Ottoman Empire, MPs stand as the most important political figures in Turkey. Unlike the United States, there are neither governors nor a President elected by universal suffrage. Party leaders usually are MPs, including the Prime Minister and the Ministers, even if the later are not necessarily MPs according to the constitution. Therefore, the Turkish political elite is primarily composed of MPs and former ones. First of all, let us consider the influence of the Parliament and then the one of the MPs in the institutional system¹.

\section{The Parliament within the institutional framework}

[2] Today, the TBMM (Türkiye Büyük Millet Meclisi, Turkish Grand National Assembly) ${ }^{2}$ can be described as a dominated actor within the institutional framework. Since the beginning of the

1 We express our gratitude to the different colleagues who have been kind enough to comment on our paper, in particular Prof. Dr. Kalaycıoğlu and Daniel Gaxie.

2 Parliament: a nation's legislative body, made up of elected and sometimes non-elected representatives. Others scholars would rather use the term National Assembly. 
Citation: Dorronsoro, Gilles and Massicard, Elise (2005) 'Being a Member of Parliament in contemporary Turkey', European Journal of Turkish Studies, Thematic Issue $N^{\circ} 3$, Being a MP in contemporary Turkey, URL: http://www.ejts.org/document502.html.

To quote a passage, use paragraph (§).

Republic, the institutional system has gone through many changes. The many institutional breaks, in general coups d'état, have weakened the position of the Parliament in the mind of the population and of the politicians themselves. Besides, the general trend has tended towards a 'rationalised parliamentarianism', which spread over Europe after WW2. Indeed, organisations controlling - directly or indirectly - the Parliament have increased in the last decades.

[3] Since the multiparty system (1946), the Parliament is an institution with a limited autonomy. After the first competitive elections, the Parliament became the centre of the political life during several decades, in spite of the coups d'état in 1960 and 1971. The 1961 constitution set up institutions to counterbalance the weight of the National Assembly, notably the MGK (Milli Güvenlik Kurumu) and even more so the Senate, part of the Senators being installed to oversee that the civilian politicians abided by the constitution. The system remained bicameral until the 1971 coup d'état.

[4] The 1982 constitution introduced a kind of 'rationalised parliamentarianism' in a securitarian regime with the MGK functioning as a parallel government (Insel 2004, Dorronsoro 2005). For instance, until very recently, the military budget remained de facto outside the control of the Parliament even if the TBMM's Defence Committee discussed the military budget with the Ministry of Defence. Questions related to the 'national security' (defined in a very extensive way) were largely decided by the MGK. Moreover, the relation between the executive and the legislative branch shows a strong and increasing influence of the President, who has the right to veto any passed law and to appeal to the Constitutional Court (Tachau 1980, Heper 1996). This evolution depends of course on the balance of powers. For example, Demirel had less influence than Özal, and the weight of Sezer is linked to the support of the military apparatus.

\section{The MPs}

[5] A weakened Parliament does not necessarily mean that MPs are not individually recognized. It is known that in some circumstances, members of the Parliament benefit from the antiparliamentarianism of the electorate. Polls indicate an important difference between popularity ratings of the Parliament and of the MPs themselves in the United States. However, according to the reports of the European Commission (European Commission 2002: 29), there appears to be a bad 
Citation: Dorronsoro, Gilles and Massicard, Elise (2005) 'Being a Member of Parliament in contemporary Turkey', European Journal of Turkish Studies, Thematic Issue $N^{\circ} 3$, Being a MP in contemporary Turkey, URL: http://www.ejts.org/document502.html.

To quote a passage, use paragraph (§).

image both of the Turkish Parliament (47\% tending to trust), of the MPs, and even more so of the parties (16\% tending to trust). It is true that the trust rate in the Italian, Spanish, Danish, and the British Parliaments are even lower, but in a 2001 TESEV survey, to be a MP is ranked as the most dishonest job by a large percentage of the population (Pérouse 2005: 226).

[6] The MPs themselves are aware that their political career could be short. Firstly, it is interesting to note the cyclical trend in the ratio of re-election during the last decades. The number of re-elected MPs is very low after brutal changes in the political offer $(1950,1960,1980,2002)$, but grows afterwards up to more or less 50\% (Massicard 2003: 33, table 8). Secondly, the duration of their mandate is precarious, since it depends not only on political reversals but also on the electoral rhythm. In this respect, we should point out that early elections are usual in Turkey: since the beginning of the multiparty system in 1946, ten out of fifteen legislative elections were early ones. Despite the fact that the article 77 of the 1982 constitution brings the term of legislature from four years - as it was since the Ottoman Empire - to five years, all elections have been early ones since then. Thirdly, the volatility of the electorate is amplified since the 1990's by important swings in the election results, showing the rejection of the parties in power. In the aftermath of the 1982 constitution and the ban on the old political parties, party identification sharply diminished and the coalition governments in the 1990's have been generally unpopular. On the whole, when the turnover is high, as it is the case since the 1990's, very few MPs are assured of being re-elected, and the threat of a removal by the electorate, by the party, or that their party doesn't reach the $10 \%$ threshold, is very present.

[7] Nevertheless, MPs are an important component in the relation between the electorate and the central power. They are able to pass on demands from the population to the centre, even if the impossibility to assume several (local and national) mandates at the same time limits in practice their influence. They also mediate between different interest groups and the centre. However, powerful lobbies such as industrialists or unions can deal directly with the government. Besides, MPs do not control much resources compared to other political actors. Indeed, the Istanbul mayors, as early as the 1960's, starting with Faruk Ilgaz and Haşim İşçan, got considerable resources form their position in local and national politics. Since metropolitan municipalities were established in 1984, their mayors detain considerable resources. Decentralisation projects might accentuate this trend and largesse out 
Citation: Dorronsoro, Gilles and Massicard, Elise (2005) 'Being a Member of Parliament in contemporary Turkey', European Journal of Turkish Studies, Thematic Issue $N^{\circ} 3$, Being a MP in contemporary Turkey, URL: http://www.ejts.org/document502.html.

To quote a passage, use paragraph (§).

of their city resources that every mayor can distribute, while most MPs fail to control significant resources.

\section{Sources and state of the question}

[8] Primary qualitative sources about MPs and parliamentarianism are relatively numerous, in contrast to the weakness of statistical and quantitative data. Besides minutes of debates in plenary sessions (which have hardly been exploited), primary sources are made up of publications from TBMM, official bulletins as well as the series of Turkey in Statistics. There are also lots of autobiographies or memoirs (Kirişçioğlu 1968, Ağaoğlu 1969, Burçak 1976, Perin 1990, Kocaoğlu 2003). Finally, we find many biographies of famous politicians - mostly party leaders - written by journalists, but which generally do not concentrate on the Parliament.

[9] On the statistical level, biographical data are unsatisfactory. About the Ottoman Empire, the work of Devereux (1963) gives a distribution by religion, ethnic group and occupation of the MPs of the 1877 Parliament (elected by a very limited college), but there is no more precise information. About the second constitutional period, from 1908 to $1918^{3}$, some works also analyse the distribution of MPs by religious and ethnic groups (Tunaya 1998, Turhan 1991: 98). Afterwards, we have various statistical works, the major empirical study being Frey's (1965), which was used in numerous studies, though never actualized in a systematic way. It gives a set of biographical information about MPs, essentially about their professional background.

[10] Otherwise, it is noticeable that many political scientists have lost interest in the functioning of the Parliament and the office of MP. For instance, Sarıbay's work of political sociology (1994) doesn't address the political elite or activities of politicians which reflects both the objectively weak position of the institution and new trends in Turkish political science. However, we can still rely on the works of Gençkaya, Hazama, Kalaycıoğlu, Özbudun and Turan (see bibliography). Turan (1985) and Kalaycıoğlu $(1988,1995,1999)$ addressed the behaviour of the MPs in the TBMM, the time spent on 'case work' as well as the committee activities of the MPs in the 1980s and the 1990s. Furthermore, there are some local studies, sometimes of great quality, describing the notables some of them being MPs - in a more anthropological way (Unbehaun 1994).

\footnotetext{
${ }^{3}$ Elections of 1908, 1912, 1914, and 1919.
} 
Citation: Dorronsoro, Gilles and Massicard, Elise (2005) 'Being a Member of Parliament in contemporary Turkey', European Journal of Turkish Studies, Thematic Issue $N^{\circ} 3$, Being a MP in contemporary Turkey, URL: http://www.ejts.org/document502.html.

To quote a passage, use paragraph (§).

[11] Since this thematic issue focuses on relations between the MPs' social background and their way to fulfil their parliamentary roles (see infra), we would like to address what has been a significant part of the literature about MPs: the relation between the political field and the society. This issue has mostly been addressed in the 1960's and 1970's by studies producing and analysing statistics about the social characteristics - mostly the professional background - of MPs. The two dominant paradigms in those studies, Marxism and developmentalism, share the same methodological presuppositions and, most of the time, their results are compatible.

[12] The study of Ünsal (1982) on the profile of the 1977 MPs falls within the scope of a critical Marxist sociology. Through the analysis of the social background of the MPs, the author notes a difference between the social composition of the TBMM and the society at large, notably the underrepresentation of the working class within the TBMM. The underlying idea is the denunciation of the confiscation of political power by the elite (Kızır 2002).

[13] Other authors have tried to show the gradual diversification of the political elite since the beginning of the Republic, in a developmentalist - thus fundamentally diachronic - way: 'Stages of political development, if not actual distributions of power, may be marked by regularities in the differential participation in formal politics of distinctive social groups' (Frey 1965: 180). They are based on the hypothesis of a relation between macro-social changes and the sociological profile of the MPs. By using statistical data on the social status of MPs (essentially their occupation, education, sex), researchers explain political developments like the institutionalisation of the political field, the professionalisation of the political elite, or the increasing pluralism among the social groups represented in the Parliament (Tachau 1980). Those results can be summed up in two statements: the diversification of the elite, and the opposition between the statist elite and those coming from other social groups.

[14] Starting from the relation between social profiles and party membership, several authors (Tachau 1980, Heper et al. 1996) notice an opposition between a group of bureaucrats and a political elite coming from the middle-class. Both social groups, through 'their' parties, fight for state resources. The (implicit) scheme is often that the bureaucracy might represent long-term interests of the country and has a stabilizing influence on the political system. Then, 'general interest' is 
Citation: Dorronsoro, Gilles and Massicard, Elise (2005) 'Being a Member of Parliament in contemporary Turkey', European Journal of Turkish Studies, Thematic Issue $N^{\circ} 3$, Being a MP in contemporary Turkey, URL: http://www.ejts.org/document502.html.

To quote a passage, use paragraph (§).

considered to be objective more than constructed, and bureaucrats as its best advocates, because they are preserved from 'populist pressure'.

[15] The second statement is the diversification of the elite. Ünsal starts from the hypothesis of an opposition between a provincial and a national elite. According to Tachau (1980: 220), the Demokrat Parti (DP) represents the interests of provincial middle-classes in the 1950's, and 'localism' - which he defines after Frey as birth in the represented district - is increasing. Later, the rise of new social groups (engineers, etc.) and the diversification of the political elite have been stressed upon. After the 1980 coup d'état, a significant proportion of religious figures - imams or graduated from imam-hatip schools - are to be found in the different parties run by Erbakan. Starting from that statement, some works, drawing on the theory of social coalitions (Tarrow 1977), assume that a political party comes to power when it manages to build an 'inter-class coalition', to pose as the representative of one or several social groups.

[16] We might call into question this paradigm through two main critics. First, data processing seems questionable. On the one hand, the construction of long statistical series while the political system has been disrupted several times, is methodologically problematic, but sometimes not even commented. In some cases, data concerning non-competitive and competitive periods are used as if they were homogenous, although continuity can hardly be established between the one-party system and the multi-party period. Moreover, the coherence of categories used to establish biographies is not called into question. For instance, the status of a profession can change in a significant way in the course of several decades, and the stable presence of a certain amount of MPs coming from one professional sector can hide changing social dynamics. On the other hand, data are insufficient, and some pieces of information are not reliable: for example, the plurality of professional experiences is rarely mentioned, most of the time because of the sources used - the TBMM albums only mention one profession. In the same way, simplified socio-professional data are favoured to the detriment of those linked to practical experiences and social skills. Finally, the selection of relevant elements in biographies is very simplified, because it does not describe personal trajectories but static social positions. Therefore, the evolution of the MP during his mandate is not taken into account, whereas fame and personal enrichment for example can alter his social position during his mandate. 
Citation: Dorronsoro, Gilles and Massicard, Elise (2005) 'Being a Member of Parliament in contemporary Turkey', European Journal of Turkish Studies, Thematic Issue $N^{\circ} 3$, Being a MP in contemporary Turkey, URL: http://www.ejts.org/document502.html.

To quote a passage, use paragraph (§).

[17] These statistical constructions are a consequence of the general hypothesis concerning the political and social fields. Developmentalist and Marxist paradigms tend to postulate simple relations between social groups and political representatives. The political system appears as a (relatively) transparent mechanism dealing with the demands of social groups. Even when addressing issues like professionalisation or institutionalisation, the autonomy of the political field and its capacity to transform social resources are put in brackets. It appears that the opposition between the bureaucratic elite and the one coming from the middle-class can be deceptive. The election of bureaucrats can be the result of their bigger capacity to mobilise state resources and to build a clientele in this way, which qualifies the idea that bureaucrats are immune to 'populist' drifts. In another way, local elites (provincial notables) are constituted in relation to the state (Meeker 2002). Besides, this duality does not work anymore in the 1970's, since there is an extreme politicisation within the institutions themselves. As a consequence, the hypothesis of a diversification of the elite led by the political development in Turkey has to be questioned. All those elements challenge the idea of a transparency between society and politics.

\section{Resources and roles}

[18] Choosing MPs as the object of study opens different options. We have decided to focus on the articulation between two paradigms, the mobilization of resources and role perspective. First, we address the issue of the mobilization of resources in the political field. The resources are defined here as what is efficiently mobilized in the political field to win election, a position of power inside a party, etc. Hence, we do not consider the social profile of the MPs per se, but the actualisation of resources in the political field. For example, it is not directly the professional background that is pertinent as such but the way the practice of a profession gives some means to enter politics. So, we have to describe the concrete mobilization of resources, for example in an electoral competition. In this perspective, the analysis of the trajectory of politicians highlights the readjustment of personal resources which permits to enter the political field (Best et al. 2000). We make the hypothesis that for the elections, the value of these resources is to be considered on a local level, since the level of electoral competition is the province. Hence, it is difficult to use data built exclusively on a national level. 
Citation: Dorronsoro, Gilles and Massicard, Elise (2005) 'Being a Member of Parliament in contemporary Turkey', European Journal of Turkish Studies, Thematic Issue $N^{\circ} 3$, Being a MP in contemporary Turkey, URL: http://www.ejts.org/document502.html.

To quote a passage, use paragraph (§).

[19] Second, the concern for the effective conditions of the practice of a political mandate leads to an analysis in terms of 'social roles' and to stress the learning of behaviours according to norms considered as legitimate (Briquet 1994: 17-18; Müller et al. 1997). In his everyday practice, a MP is constantly compelled to signify his conformity to a set of norms that define his role. Entering the role implicates having the practical knowledge of what is convenient to do when one has to fit into successive interactions. These ascriptions of roles are multiple and heterogeneous since roles are defined by formal and informal ascriptions from different actors, juridical norms, etc. Elected people are interacting in different social spaces, which are not necessarily structured by specifically political principles. The ascriptions of roles are contextual: they depend on the characteristics of the publics to which one is confronted. As such, they are not necessarily homogeneous at the national level. Behaviours expected from a MP are a product of a particular, sometimes localized, configuration, and might appear weird in other parts of the country. 'The concept of 'role-set' is to be distinguished from the concept of 'multiple roles', which are associated not with a single social status but with the various statuses in which individual operates' (Saafeld 1997: 39-40).

[20] Our endeavour is to link the question of resources with that of roles. In the same perspective, Turan (1985) linked the practise of transfers from one party to another with the resources of the MPs. In a first step, we see how the political field is characterised by mechanisms of selection and transformation of resources. The analysis of the trajectories of MPs, through their initial resources (before their election), the accumulation of specific resources during the mandate, and then their possible retaining afterwards, is intended to test the hypothesis of the 'autonomisation' of the political field. In a second step, we deal with the complex role-set of MPs, which can be analysed through three loci: within the party, within the Parliament, within the constituency. From this, we will question the relation between the resources of MPs and the way they interpret and fulfil their roles. Because of the many institutional breakdowns, the temporal scope of the core analysis begins after 1980, even if a broader historical perspective is taken in account in some papers. Let us first present the resources perspective, then the role perspective, keeping in mind that this distinction is only analytical, and does not imply any determinist causal relation. 
Citation: Dorronsoro, Gilles and Massicard, Elise (2005) 'Being a Member of Parliament in contemporary Turkey', European Journal of Turkish Studies, Thematic Issue $\mathrm{N}^{\circ} 3$, Being a MP in contemporary Turkey, URL: http://www.ejts.org/document502.html.

To quote a passage, use paragraph (§).

\section{The resources and their transformation}

[21] Since we take into account the transformation of resources as a dynamic and temporal phenomenon, we address first the resources of the MPs before the election and their local value, then the trajectories of MPs during and after their mandate. On this basis, we shall then question the professionalisation of MPs.

\section{Non-political resources}

[22] Non-political resources mobilized in the political field can be listed in a non-exhaustive way as economic capital, proximity to state institutions, professional skills, activism, social capital, local roots, religious charisma, and family membership. In that sense, available data are often insufficient to give a clear view of these resources, and their reduction to the very profession would be deceptive. These resources work in different ways according to periods and places; some can be illegitimate for some time. For instance, if we exclude the first Parliament, it was very exceptional for a man whose main profession involved religious matters, to become an MP (Kocak in this issue). The religious charismatic resource has been de facto forbidden for a candidate before 1946 and after the different coup d'état, but favoured in the 1980's and 1990's by the centre-right parties like ANAP, DYP, and Islamist parties such as RF and FP (Dorronsoro in this issue). In a diachronic perspective, we can also ask why certain kinds of capital are more easily transferable in the political field according to socio-economical situations. For instance, the presence of engineers is probably linked, more than to a questionable rise of the middle-class, to a change in the organisation of this profession and to the emergence of a technicist discourse in politics (Göle 1990).

[23] During the single-party period, professional profiles like high rank army members and bureaucrats who had reached the higher echelons in state administration could be rewarded after their retirement by being made MPs. These civil servants formed the most crowded group in Parliament. According to Frey's study (1965: 114-122), the rate of this group in the Parliaments of the single-party period ranged from $23 \%$ to $57 \%$. The number of parliamentarians who were selfemployed, as well as tradesmen and industrialists from the 'private enterprise', were much lower (Koçak in this issue). Another resource which was valorised was regime loyalty for the country's 
Citation: Dorronsoro, Gilles and Massicard, Elise (2005) 'Being a Member of Parliament in contemporary Turkey', European Journal of Turkish Studies, Thematic Issue $N^{\circ} 3$, Being a MP in contemporary Turkey, URL: http://www.ejts.org/document502.html.

To quote a passage, use paragraph (§).

forthcoming artists, writers, poets and journalists. They were often made MPs, but were also supposed to be foremost spokesmen of the regime (Günay in this issue).

[24] How are the professional resources used in the political field? According to the results of Frey (1965), completed by later studies, three professional groups are over-represented within the Turkish Parliament: bureaucrats and lawyers in the early Republic, and engineers since the 1970's. As we have seen, the number of civil servants is important during the one-party period before decreasing regularly, whereas liberal professions experience a parallel rise, notably just before the multi-party system (Frey 1965, Tachau 1980: 207). Within this group, lawyers are the most numerous, except in 1957.

[25] Frey explains the importance of the lawyers by the capacity to resume one's initial job and a 'natural' link between the occupations of lawyer and of MP (Frey 1965: 111-112). We can challenge these explanations by questioning instead social dispositions and professional habitus gained through accomplishing a profession, and their later use in the political field. So, we can analyse how specific resources linked to the profession of lawyer are reinvested in the political field. In Turkey, the presence of lawyers can be interpreted in different ways according to the period. Until the 1960's, the lawyer is seen as a notable. Hence, his election as a MP is linked to his local status. After the 1970's, we can emphasis the role of the professional chambers as a locus of politicisation (Bora 2000, Dorronsoro in this issue).

[26] In some cases, the initial profession is the gate to enter politics, but at the same time renders the day-to-day MP's occupation difficult, since the two professional habitus are deeply contradictory. Günay in her essay underlines that some writers co-opted to the one-party Parliament as prestigious intellectuals or, in later periods, as ordinary competitors in the election process have often disturbed the power holders either as MPs in their parliamentary activities, or as writers in their literary work, and sometimes as both.

\section{The value of resources}

[27] The value of the resources is to be defined in relation to the local political field. The characterization of the local political field is complex; thus, when Tachau underlines the differentiated profile of the MPs according to the level of development of their constituency (1980), the choice of 
Citation: Dorronsoro, Gilles and Massicard, Elise (2005) 'Being a Member of Parliament in contemporary Turkey', European Journal of Turkish Studies, Thematic Issue $N^{\circ} 3$, Being a MP in contemporary Turkey, URL: http://www.ejts.org/document502.html.

To quote a passage, use paragraph (§).

this unique criterion is problematic. Here comes the question of the varying political value of resources in different contexts. For instance, inherited charismatic religious capital is largely confined to some regional (mainly, but not only, South-Eastern) and social (rural or little cities) contexts, while other resources seem really national. In a mostly Kurdish-populated province like Diyarbakır, militants without any notoriety or social capital can be elected to a major city on the list of a Kurdist party in municipal elections (Dorronsoro in this volume). Belonging to a mezhep (Alevi or Sunnite) can constitute a major resource as well in contexts of differentiation or tension like in the late 1970's (Cumhuriyet 1977). Thus, resources have a specific value depending on the local political field.

[28] According to Tachau (1980), MPs are increasingly oriented towards 'localism', because they are more and more born in the constituency where they are elected. However, this fact is difficult to interpret, because it postulates a natural relation between place of birth and the ability to mobilize local resources. Instead, it seems relevant to reflect upon the local use of national resources and vice-versa. In other words, the 'local' can be constituted as a resource in different ways: first, the 'local' can be constructed as a legitimising category in political discourses and media; second, party apparatus can establish hemşehri associations, or links can be formed between both (Schüler 1998, Kurtoğlu 2004, ejts 2005). In that way, a pitchforked candidate can take benefit from a strong local presence, if he enjoys the support of a local party apparatus.

[29] During the single-party period, the 'local' was sometimes valorised as a political resource, sometimes not. Some parliamentarians had never ever been to the region they were elected from, and, possibly, were never ever to visit this region as MPs, either. It was not uncommon for those who were to become MPs to hear about this either through the dailies or through radio news. It would be very hard to state that these parliamentarians really did represent 'their' regions. From time to time some of them were re-elected from entirely different regions. By contrast, there were also parliamentarians who were born in and had grown up in the region from which they were elected. These had a certain kind of relationship to the region, for they were the 'wealthy' of the region. Especially in areas of the country where a feudal agricultural structure prevailed, wealthy landowners were constantly in Parliament as MPs. In particular, the notables, who had positive and close relations with party headquarters, easily entered and were able to remain in Parliament. Therefore, local ties were sometimes valorised by the Kemalist regime (Koçak in this issue), depending however on the political situation in the region. For example, during the military 
Citation: Dorronsoro, Gilles and Massicard, Elise (2005) 'Being a Member of Parliament in contemporary Turkey', European Journal of Turkish Studies, Thematic Issue $\mathrm{N}^{\circ} 3$, Being a MP in contemporary Turkey, URL: http://www.ejts.org/document502.html.

To quote a passage, use paragraph (§).

administration of the South-East, most of the Diyarbakır MPs were civil servants with no local ties; but all MPs elected in 1946 - at the beginning of the multiparty period - were local notables (Dorronsoro in this issue).

\section{The accumulation of specific resources during the mandate}

[30] The MP mandate is only a moment in a personal trajectory. How do MPs take advantage of the resources accumulated during mandate afterwards? In a dynamic perspective, the mandate especially the first of a MP - is a period when the MP social status is changing. From an anecdotic point of view, former MPs' visiting cards almost always mention their former position, which indicates a willingness to put to the fore the social capital associated with it. Investing in politics represents a risk; resources can increase or, in some cases, decrease. For instance, a notable - with an important initial social capital - whose passage in politics is marked by scandals can lose part of his respectability. As they expose publicly their political preferences during their mandate, professionals can alienate some of their former clients (Massicard in this issue).

[31] Resources accumulated during the mandate may vary depending on how the roles have been fulfilled. In general, we can assume an accumulation of social capital, because the role of the MP puts in contact individuals and institutions. The MP benefits from a modest wage and numerous advantages in nature (even if the accommodations were recently withdrawn). But, more important, economical capital can be acquired irregularly, for example through public contracts (ihale), a possibility which may not be accessible for all MPs, but only MPs from the party in power or with good connections to decision-making bodies. Indirectly, the relations created with bureaucrats and politicians as an MP can be useful and possibly help to increase one's economic capital during or after the mandate.

[32] For the 1920-1946 period, Koçak suggests that some parliamentarians would quit Parliament in order to become ambassador or governor. Those who worked in the public service in deep loyalty to the regime could return to their former duties, if they wished. Being a deputy was just another way of being in the public service. The MPs, who additionally became Ministers, formed an even narrower group, as the turnover was quite low. For the multiparty period, Dorronsoro underlines that a significant part of Diyarbakır MPs tend to settle in Istanbul or Ankara after their mandate, a fact 
Citation: Dorronsoro, Gilles and Massicard, Elise (2005) 'Being a Member of Parliament in contemporary Turkey', European Journal of Turkish Studies, Thematic Issue $N^{\circ} 3$, Being a MP in contemporary Turkey, URL: http://www.ejts.org/document502.html.

To quote a passage, use paragraph (§).

which can be interpreted as a part of the formation of a national elite and the professionalisation of politics.

\section{Professionalisation and autonomy of the political field}

[33] The existence of a specialized political field leads to consider the professionalisation of political agents through a set of questions. The professionalisation of politicians and the rationalization of this occupation should be distinguished. Whereas professionalisation is generally linked to the central rule of parties, notably in Germany (Saafeld 1997), rationalisation as an expertise - the mobilisation of specific techniques requiring important resources showing through notably during election campaigns, political marketing, etc. - may not be necessarily linked to parties. In some cases, candidates benefiting from enough resources can display the same level of rationalization than candidates supported by a party, relying for example on lobbies.

[34] In this respect, the contributions of this issue point in two directions. First, political parties are more and more necessary to enter politics in Turkey; however, this does not imply a strong tendency to the professionalisation of the MPs. The independent MPs, that is to say the ones who do not belong to a party, are rare and show a contrario the importance of the parties ${ }^{4}$. In the case of Diyarbakır, political resources are decisive in the political competition (Dorronsoro in this issue). At the same time, a large part of the MPs have no long political experience. The point here is the functioning of the political parties in Turkey and the very centralized way in which the candidate are designated. In most cases, the leader and his close cronies choose the MPs, often on the base of personal loyalty.

[35] Second, the level of autonomy of the political field is varying, as well as its ability to influence other social fields (for the relations between the political and the literary field, see Günay in this issue). Periods of crisis and periods of routine should be distinguished, since they affect the autonomy of the political field. Crisis of the political system (declining objectivisation of social roles, institutional breakdowns, etc.) permit a 'dedifferentiation' of the fields. In other words, in spite of the

${ }^{4}$ To be elected as independent, a candidate has to get $20 \%$ of the votes of the constituency in which he runs. Deputies elected as independents had disappeared from the Assembly after 1980, but they reappeared in 1999 with three deputies. In 2002, nine independents were elected out of 260 independent candidates in whole Turkey (Sarıdoğan 2003). 
Citation: Dorronsoro, Gilles and Massicard, Elise (2005) 'Being a Member of Parliament in contemporary Turkey', European Journal of Turkish Studies, Thematic Issue $N^{\circ} 3$, Being a MP in contemporary Turkey, URL: http://www.ejts.org/document502.html.

To quote a passage, use paragraph (§).

tendency toward a professionalisation of political elites, the inverse mechanism can be observed during periods of crisis, with the opening of the field to outsiders. The 2002 legislative elections, with the multiplication of parties, an important turnover of MPs, and the strong presence of MPs without political experience (Massicard in this issue), can be an example. Thus, we might find an important opening of the field in those contexts: the investment of resources in the political field is then facilitated, the entrance ticket is low, even for the creation of parties, and non-political attributes are valorised. Logically, we find a correlation between periods of crisis and a growing presence of nonpolitical capitals (Dorronsoro in this issue).

\section{Roles and resources}

[36] Who defines the role of MP? First, there is a juridical definition of the role of MP. Legal norms define institutional roles (regulations of parties about the designation of candidates, poll systems, degree of 'rationalization' of the parliamentarian system, etc).

[37] Second, the parties have very strong role prescriptions concerning MPs. These role prescriptions are even more important since the MPs highly depend on their party for re-election (see infra).

[38] Third, the ascription of roles also comes from the representations concerning the MPs. What are they in contemporary Turkey? First, there are representations of politics by those who practice it, elected representatives themselves, through their discourses in terms of moral obligation or their believing in legitimacy given by election. But there are also representations among the electorate about efficiency, the place given to service (hizmet), about what is licit and what is illicit. The construction by journalists of the occupation of MP is of great importance in the formation of the ascription of roles, even if representatives themselves are far from being passive. Turkish MPs are relatively absent in the media, except party leaders and when some incidents like scuffles occur in Parliament. Parliamentary debates are broadcast on TRT, but they rarely appear in newspapers. Violence - verbal, but also physical - occurs from time to time, leading to scandals: it is perceived as such a transgression of the proper behaviour of a MP that it is then broadcast in the news bulletin (Günay and Aslan-Akman in this issue). Through those performances, representations of elected members do constrain their behaviour. 
Citation: Dorronsoro, Gilles and Massicard, Elise (2005) 'Being a Member of Parliament in contemporary Turkey', European Journal of Turkish Studies, Thematic Issue $N^{\circ} 3$, Being a MP in contemporary Turkey, URL: http://www.ejts.org/document502.html.

To quote a passage, use paragraph (§).

[39] The main tasks recognized to MPs are first, legislative activities which are constituted as follow: work in parliamentary committees; parliamentary debates (when and how do MPs intervene in the proceedings?), and speeches from the desk (written and oral questions to the government) (Bakırcl 2000). Besides the legislative activities, another task recognised to MPs consists of transmitting individual requests - in general, but not exclusively, from their electorate - and answering them. This role is both legitimate (a MP has to be at the service of the people and accessible to its requests) and illegitimate (as far as these practices are often disparaged as being particularistic, flouting the public good and the general interest) (Güneş-Ayata 1994: 62). Despite of this ambiguity, it is quasi institutionalised, since parliamentary sessions start at $15 \mathrm{pm}$, and mornings are devoted to visits. One may observe queues of unequal size, but sometimes really impressive, in front of MPs' office. This role of resort is all the more marked since MPs are often seen as being very powerful, although themselves are quite aware of the limits of their power.

[40] MPs learn on the job (Kocaoğlu 2003); thus, the learning process varies from one individual to another: it depends on the conditions of access to deputation, according to whether they have been active in a party and assumed responsibilities in it, whether they have involved in the associative or trade-union work, or whether their good fortune is due to supports outside the political field. Thus, the apprenticeship of the roles also depends on the social properties of the candidates, because they predispose them more or less to assume the prescribed rules. Meetings - sometimes informal - of elected representatives and what happens behind the scene permit the circulation of practical know-how, warnings and advices. Information and knowledge necessary to fulfil obligations linked to the roles are thus transmitted.

[41] The process of learning to be a MP is comparable to the apprenticeship of know-how and of knowledge constituting roles, which catch MPs with variable intensity and different kinds of obligations according whether they subscribe to it with conviction, reason or duty. Therefore, ascriptions of roles are constraints for MPs, their personal history having prepared them more or less to accept. There seem to be no strong standardization of role learning in Turkey, neither through the main ways of transmission of political roles (party and elected offices) nor through the professionalisation of legislative activity (Massicard in this issue). The conditions in which MPs learn the political occupation show that the socialisation can only be limited and that habitus are only marginally modified. 
Citation: Dorronsoro, Gilles and Massicard, Elise (2005) 'Being a Member of Parliament in contemporary Turkey', European Journal of Turkish Studies, Thematic Issue $N^{\circ} 3$, Being a MP in contemporary Turkey, URL: http://www.ejts.org/document502.html.

To quote a passage, use paragraph (§).

[42] The political occupation leads to interact in several social worlds (Lagroye 1994). Being a representative implicates being able to play different roles, which may also appear to be contradictory (Briquet 1994, Müller et al. 1997). Empirical evidence suggests that the problem of disturbances in role-sets is a very real one for modern Members of Parliament.' (Saalfeld 1997: 40). These contradictory role ascriptions are perceived as such by the MPs, even if interiorized differently (Massicard in this issue). Whatever the MP's dominant characteristic (a grassroots candidate or a candidate supported by a party), the role he is said to incarnate or the one he is favouring, he has to take into account the plurality of his roles. One may observe them through the succession of behaviours and ways of being in everyday practices of MPs, obliging them to resort to different legitimacy registers. Thus, MPs use different know-how, practices and beliefs, which they cannot forget without taking the risk to offend one of the publics they are in relation with. In some cases, behaviours of MPs within the Parliament can interfere with the voters' requests and their responsibilities in their party. Sometimes, parliamentary sessions start late or are cancelled because of the absence of quorum, or because MPs, busy with some other tasks, are not available.

[43] How do individuals take prescribed roles up? The ways to fulfil these roles depend notably on the resources of MPs, leading them for example to attend or to escape public meetings, to engage more or less in legislative work, etc. (Massicard in this issue). For example, MPs without political experience, put on the list by a party mainly because of their extra-political skills which can be useful for parliamentary activities, will mostly engage more in legislative work than, say, MPs elected with strong personal social support, and who depend less on their party's backing (Massicard in this issue). Therefore, new social profiles among MPs can lead to changes in the ways to practice this occupation (Norton 1997).

\section{The centrality of the party}

[44] To understand the MPs occupation in the Parliament, the relations between MPs and their parties are central. All the essays in this issue (Aslan-Akman, Günay, Koçak, Massicard) underline the central role of the parties in the day-to-day activities of the MP in the TBMM. It is not supposed here that every party is organised in the same way, the importance of elected members is obviously different for instance in ANAP and MHP and may evolve in every party. 
Citation: Dorronsoro, Gilles and Massicard, Elise (2005) 'Being a Member of Parliament in contemporary Turkey', European Journal of Turkish Studies, Thematic Issue $\mathrm{N}^{\circ} 3$, Being a MP in contemporary Turkey, URL: http://www.ejts.org/document502.html.

To quote a passage, use paragraph (§).

[45] The centrality of the parties derives both from institutional regulations and political rationality. Firstly, the 1982 constitution and the Rules of Procedure adopted in 1996 aimed to increase the efficiency of the Parliament, thereby limiting the autonomy of the individual MPs, reinforce the place of the party group (Gençkaya 1999). Secondly, the great majority of representatives are in a state of dependence vis-à-vis the parties for their re-election. Because of the electoral system, the major step for the MP is his nomination by the party on an eligible position in the list more than the electoral campaign itself. The fact that the parties determine a candidate's election more than his personal resources affects the MPs' behaviour within the Parliament, for example in relation to party discipline.

[46] In this respect, the centrality of the parties has increased since the 1980s. Turkish electoral history contains multiple experiences regarding how candidates move from the status of 'candidate to the candidature' - which requires only fulfilling some forms and paying some amount of money - to that of 'candidate to MP', designated by a party. In particular, a procedure in which the electorate was able to express his preference for one candidate was in force during the 1961, 1973, 1977 and 1991 legislative elections ${ }^{5}$, and was then abolished. After 1961, the electoral law compelled the parties to organize primaries to designate the candidates, and only exceptionally allowed nomination by the direction of the parties - in case of lack of local candidates or deficiency of the local organisation. Nevertheless, since 1986, this obligation has been abolished. Now, every party can designate candidates either directly or by internal elections. However, internal elections are nowadays an exception, which paves the way to party oligarchy. Despite of sporadic protestations, directions of parties remain almost omnipotent in this domain, which may explain the fact that lots of candidates are pitchforked and that directors of local branches of parties are often bypassed concerning the nomination of candidates. Even if mechanisms of negotiation between parties and candidates to the candidature during pre-electoral periods should be analysed more thoroughly, the eventual re-election of MPs is submitted to the approbation of their candidature by the direction of the party, which is not automatic.

5 In the 1991 legislative elections, it was possible for the voters to register a voice for a specific candidate, who by getting an endorsement from a minimum of $15 \%$ of the voters could be moved up to the top of the list (Kalaycıoğlu 1995: 46). 
Citation: Dorronsoro, Gilles and Massicard, Elise (2005) 'Being a Member of Parliament in contemporary Turkey', European Journal of Turkish Studies, Thematic Issue $N^{\circ} 3$, Being a MP in contemporary Turkey, URL: http://www.ejts.org/document502.html.

To quote a passage, use paragraph (§).

[47] Many clues indicate that parties constrain MPs' behaviour, at least concerning the discipline of vote. We shall now see in details the weight of party in the organization of the MPs' work and then their level of autonomy. Is the legislative activity of a MP correlated to his place in the party? The first point here is that the party group decides upon the attribution of the different parliamentary positions, i.e. member or chair of a committee etc., which in turn highly constraints the MPs' roleorientation (Massicard in this issue).

[48] The second point is that the political configuration can define the MP as an opposition MP with a specific role. Aslan-Akman focuses on CHP MPs with a strong position in the party in the precise context of the $22^{\text {nd }}$ Assembly characterized by a high level of polarization between the two parties. In her essay, she shows that the behaviour of MPs of the main opposition party is both strongly constraint by rules of procedure and defined by the party, may be leading to the 'existence of an opposition MP role'.

[49] A way for MPs to escape party pressure is to change party, a common practice of transfers since the beginnings of multiparty politics. Historically, there have been high levels of interparty mobility in the Turkish Parliament. The elected representatives are able to move quite easily from a party to another, for instance if they think that they are not positioned at an eligible level on the list, or that their party won't go through the 10\% threshold (Massicard 2003). At least before 1980, party changing appears to improve career prospects (Turan 1985). In his first account of the specific profile of the party changers, Turan (1985) showed that, in the case of individual transfers, party changers tended to come more from small and least developed constituencies.

[50] As political contexts influence party changing decisions by individual deputies and factions, Turan's paper in this issue examines the developments of inter-party mobility since the 1980s (Turan et al.). Feeling that party changing not only encouraged political instability and was unethical, and fearing that it might undermine the two-party system they were trying to build, the military makers of the 1982 constitution introduced measures to prevent it. These failed to stop the mobility of deputies who found many ways to circumvent restrictions to move between parties. However, an interesting difference with the period before 1980 is that individual party changers and non-changers do not appear any more to have different attributes. It would be interesting to investigate further if changers and non-changers show differences in terms of resources. Is party- 
Citation: Dorronsoro, Gilles and Massicard, Elise (2005) 'Being a Member of Parliament in contemporary Turkey', European Journal of Turkish Studies, Thematic Issue $N^{\circ} 3$, Being a MP in contemporary Turkey, URL: http://www.ejts.org/document502.html.

To quote a passage, use paragraph (§).

changing correlated to some special way to behave as a MP, for example constituency-service orientated?

\section{MPs and their constituencies}

[51] Another important dimension of the MP's occupation is his relation to his constituency. It is the service and allocational aspects of responsiveness that compose the most frequent demands of constituents to parliamentarians in Turkey. In terms of daily activities, parliamentarians spend for constituency service the largest part of their time at their own disposal (Hazama in this issue). What do we know about the interactions about MPs and their constituents? Localised studies like those of Güneş-Ayata (1990), and Unbehaun (1994), without focusing on the local role of MPs, set on MPs in a context of interaction among bureaucrats, local politicians and notables. By doing so, they give sometimes sketchy, but interesting indications concerning the role of MPs in their constituency. However, almost all these case studies deal with rural Turkey or small towns. But in a widely urbanised society, it is risky to generalise clientelist relations, which are by definition encompassing and undifferentiated. Modalities of exchange are probably different in urban contexts. Attempts to grasp them there in a more precise way (Erder 1996, Schüler 1998, Kurtoğlu 2004) have not really dealt with MPs and their role in the relation between electors and parties.

[52] It is then important to clarify the different dimensions of the relation between MPs and their constituents. The term constituency service includes different kinds of activities: mainly personal services to the citizens, activities encouraging infrastructural services or job-creating investments in the constituency or more generally collective goods, which are often related to collective actors like local lobbies. Personal services is what legislative studies usually call 'case work' and what is often called in Turkish hizmet: Kalaycıoğlu (1995) asserts that constituents approach MPs for three main reasons: to find jobs, to get promotion or transfers at a certain job, and to seek health care. One also expects MPs to help to go through the bureaucracy.

[53] Why are MPs doing hizmet? In a proportional representational system, Turkey's province-size constituencies generate a significant size of personal votes for a candidate, though nominated in the party list. On the base of a questionnaire on the XIXth Assembly - an Assembly elected with preference system and, for some parties, primaries - Hazama explores how and to what 
Citation: Dorronsoro, Gilles and Massicard, Elise (2005) 'Being a Member of Parliament in contemporary Turkey', European Journal of Turkish Studies, Thematic Issue $N^{\circ} 3$, Being a MP in contemporary Turkey, URL: http://www.ejts.org/document502.html.

To quote a passage, use paragraph (§).

extent parliamentarians are responding to demands from constituents and why they do so. Second, for the purpose of re-election, parliamentarians consider their individual activities to be almost as important as the party popularity. Those activities are publicized through the local media, including the press, the most important of which, however, being the constituents that they meet in person.

[54] Do the characteristics of the constituency orientate the role of the MP toward constituency service? According to Hazama, the demand for and supply of constituency service depend on different politico-economic structures of the constituency (Hazama in this issue). The smaller the constituency size, the larger will be the demand for and the supply of constituency service. This is because in small constituencies parliamentarians are more recognizable by their constituents and the weight of personal votes is larger than in large constituencies. Thus, even under proportional representation, relatively small constituencies in Turkey make constituency service important for parliamentarians seeking re-election. In addition, since the Turkish parliamentarian's turnover rate is very high, even re-elected parliamentarians have to take constituency service seriously. The statistical test showed no significant difference in the practices of constituency service between newly elected and re-elected parliamentarians. Massicard suggests that MPs from big cities are faced with less direct representative duties. But the downside is that these MPs have a much harder time than their colleagues from smaller constituencies to get their names and pictures into the newspapers on a regular basis or to answer the demands in a way that can bring sizeable social support. In a constituency like Istanbul, it is very difficult to construct a local base (Massicard in this issue).

[55] Which kind of MPs tries to increase their local resources, or to take the role of local representatives? Massicard suggests that MPs elected without strong local support hardly entertain any kind of localism, probably because social support is an insecure resource, and enhancing it may appear more time and energy-consuming than, say, demonstrating loyalty to the party. It seems that social support is a resource which is invested by MPs as a secondary choice or as a complement to other resources. However, having a social strategy for a MP is not necessarily outside the party, since some parties tend to encourage their MPs to do constituency service. 
Citation: Dorronsoro, Gilles and Massicard, Elise (2005) 'Being a Member of Parliament in contemporary Turkey', European Journal of Turkish Studies, Thematic Issue $N^{\circ} 3$, Being a MP in contemporary Turkey, URL: http://www.ejts.org/document502.html.

To quote a passage, use paragraph (§).

\section{Conclusions}

[56] There is a theoretical profit in displacing the analysis from the MPs' biographies to the resources they mobilize. The downside is that new data have to be produced, since the exiting ones are not tailored to this approach. In order to understand the resources mobilized both in political campaigns and during the MP mandate, more attention should be drawn to the activities in the constituencies. This in turn implies working at the constituency level, which is where electoral competition takes place and the relative value of resources can best be understood. Working on resources also constitutes an empirical way to address the autonomy of the political field which, in the Turkish case, varies heavily as shown by the strong and punctual increase of non-political resources mobilized by MPs in times of crisis.

[57] There is a relation between the resources mobilized by the MPs and the way they fulfil their roles. This issue indicates that the parties are central not only in the administrative functioning of the Parliament and for the MPs' career, but also in the very definition of individual MPs' roleorientation. The centrality of the relation to the party in role-orientation, however, does not necessarily imply increasing professionalisation. As a matter of fact, non-partisan and non-political resources especially professional ones - can strongly impact the role-orientation, but also be decisive in the very selection of MPs by parties. As a consequence, strong contradictions between previously acquired non-political professional habitus and values, and the MP role-set, are likely to appear, resulting on role-conflict. Finally, constituency service appears to be less central in defining role-orientation than the party, even if it is spectacular and often time-absorbing for the MPs. 
Citation: Dorronsoro, Gilles and Massicard, Elise (2005) 'Being a Member of Parliament in contemporary Turkey', European Journal of Turkish Studies, Thematic Issue $N^{\circ} 3$, Being a MP in contemporary Turkey, URL: http://www.ejts.org/document502.html.

To quote a passage, use paragraph (§).

References

General studies

Abélès, Marc (1989) Jours tranquilles en 89. Ethnologie politique d'un département français, Paris, Odile Jacob.

Abélès, Marc (2000) Un ethnologue à l'Assemblée, Paris, Odile Jacob.

Best, Heinrich; Cotta, Maurizio (eds.) (2000) Parliamentary Representatives in Europe, 1848-2000. Legislative Recruitment and Careers in Eleven European Countries, Oxford, Oxford University Press.

Bourdieu, Pierre (1981) 'La représentation politique. Eléments pour une théorie du champ politique', Actes de la Recherche en Sciences Sociales 36-37, pp. 3-24.

Bredin, Frédérique (1997) Députée, Journal de bord, Paris, Fayard.

Briquet, Jean-Louis (1994) 'Communiquer en actes. Prescriptions de rôles et exercice quotidien du métier politique', Politix 28, pp. 16-26.

Briquet, Jean-Louis (1997) La tradition en mouvement. Clientélisme et politique en Corse, Paris, Belin.

Buron, Robert (1963) Le plus beau des métiers, Paris, Plon.

Cayrol, Roland ; Parodi, Jean-Luc ; Ysmal, Colette (1973) Le député français, Paris, Presses de la Fondation Nationale des Sciences Politiques.

Chapoulie, Jean-Michel (1973) 'Sur l'analyse sociologique des groupes professionnels', Revue française de sociologie 14 (1).

Dobry, Michel (1986) Sociologie des crises politiques, Paris, Presses de la FNSP.

Dorrandeu, Renaud (1994) 'Les métiers avant le métier. Savoirs éclatés et 'modèle notabiliaire", Politix 28, pp. 27-34.

Escarras, Jean-Claude ; Imperiali, Claude ; Pini, Robert (1971) Courrier parlementaire et fonction parlementaire, Paris, PUF.

Fenno, Richard F. Jr. (1966) The Power of the Purse. Appropriations Politics in Congress, Boston, Little Brown.

Fenno, Richard F. Jr. (1973) Congressmen in Comittees, Boston, Little Brown.

Fenno, Richard F. Jr. (1978) Home Style. House Members in their Districts, Boston, Little Brown.

Fenno, Richard F. Jr. (1990) Watching Politicians. Essays on Participant Observation, Berkeley, IGS Press/Institute of Governmental Studies/University of California at Berkeley.

Fenno, Richard F. Jr. (1996) Senators on the Campaign Trail. The Politics of Representation, Norman, University of Oklahoma Press.

Fenno, Richard F. Jr. (2000) Congress at the Grassroots. Representational Change in the South, 1970-1998, Chapel Hill, The University of North Carolina Press. 
Citation: Dorronsoro, Gilles and Massicard, Elise (2005) 'Being a Member of Parliament in contemporary Turkey', European Journal of Turkish Studies, Thematic Issue $\mathrm{N}^{\circ} 3$, Being a MP in contemporary Turkey, URL: http://www.ejts.org/document502.html.

To quote a passage, use paragraph (§).

Fontaine, Joseph ; Le Bart, Christian (1994) Le métier d'élu local, Paris, L'Harmattan.

Garraud, Philippe (1984) 'Sociologie des élus locaux', Les cahiers du CFPC 14.

Garraud, Philippe (1989) Profession Homme politique. La carrière politique des maires urbains, Paris, L'Harmattan.

Garraud, Philippe (1991) 'Métier politique et statut de l'élu local', Les cahiers du CNFPT 32.

Gaxie, Daniel (1973) Les professionnels de la politique, Paris, PUF.

Grezes-Rueff, François (1994) La culture des députés français (1910-1958). Essai de typologie, Toulouse, Presses Universitaires du Mirail.

Guiral, Pierre ; Thuillier, Guy (1980) La vie quotidienne des députés en France de 1871 à 1914, Paris, Hachette.

Heper, Metin; Evin, Ahmet (eds.) (1988) State, Democracy and the Military, Berlin, de Gruyter.

Lagroye, Jacques (1994) 'Être du métier', Politix 28, pp. 5-15.

Loewenberg, Gehrard; Patterson, Samuel C.; Jewell, Malcom E. (eds.) (1985) Handbook of Legislative Research, Cambridge, Harvard University Press.

Mabileau, Albert (dir.) (1993) A la recherche du "local", Paris, L'Harmattan.

Masclet, Jean-Claude (1979) Le rôle du député et ses attaches institutionnelles sous la Ve République, Paris, LGDJ.

Meynaud, Jean (1961) 'La profession parlementaire', Revue Internationale des Sciences sociales, 13(4).

Müller, Wolfgang C.; Saalfeld, Thomas (eds.) (1997) Members of Parliament in Western Europe. Roles and Behaviour, London, Franck Cass.

Neveu, Erik (2003) 'Métier politique : d'une institutionnalisation à une autre', in Lagroye, Jacques (dir.), La politisation, Paris, Belin, pp. 103-121.

Norris, Pippa (ed.) (1997) Passages to Power. Legislative Recruitment in Advanced Democracies, Cambridge, Cambridge University Press.

Norton, Philip (1997) 'Roles and Behaviours of British MPs', in Müller, Wolfgang C.; Saalfeld, Thomas (eds.), Members of Parliament in Western Europe. Roles and Behaviour, London, Franck Cass, pp. 17-31.

Norton, Philip (ed.) (1998) Parliaments and Governments in Western Europe, London, Frank Cass.

Norton, Philip (ed.) (1999) Parliaments and Pressure Groups in Western Europe, London, Frank Cass.

Norton, Philip (ed.) (2002) Parliaments and Citizens in Western Europe, London, Frank Cass.

Norton, Philip; Wood, David M. (1993) Back from Westminster. British Members of Parliament and their Constituents, Lexington, University Press of Kentucky.

Offerlé, Michel (1999) La profession politique : XIXe-XXe siècles, Paris, Belin. 
Citation: Dorronsoro, Gilles and Massicard, Elise (2005) 'Being a Member of Parliament in contemporary Turkey', European Journal of Turkish Studies, Thematic Issue $N^{\circ} 3$, Being a MP in contemporary Turkey, URL: http://www.ejts.org/document502.html.

To quote a passage, use paragraph (§).

Phélippeau, Eric (2002) L'invention de l'homme politique moderne : Mackau, l'Orne et la République, Paris, Belin

Saalfeld, Thomas (1997) 'Professionalisation of Parliamentary Roles in Germany: An AggregateLevel Analysis, 1949-1994', in Müller, Wolfgang C.; Saalfeld, Thomas (eds.), Members of Parliament in Western Europe. Roles and Behaviour, London, Franck Cass, pp. 32-54.

Tarrow, Sidney (1977) 'The Italian system between crisis and transition', American Journal of Political Science 21 (2), pp. 193-224.

Wahlke, John C.; Eulau, Heinz; Buchanan W.; Ferguson L. C. (1962) The Legislative System. Explorations in Legislative Behavior, London, J. Wiley.

'Le métier d'élu - jeux de rôles', Politix n²8, 1994.

\section{On Turkey}

Akın, Rıdvan (2000) Türkiye Büyük Millet Meclisi'nin Birinci Döneminde Devlet Erkleri ve İdare, Doktora Tezi, Sosyal Bilimler Enstitüsü, İstanbul Üniv., Pr. Dr. Erdoğan Teziç, 509 p.

Arat, Yeşim (1989) The Patriarchal Paradox. Women Politicians in Turkey, Rutherford, Fairleigh Dickinson University Press.

Aslan, Canan; Güneş-Ayata, Ayşe (2004) 'Türkei: Die Überwindung der Ungleichheit zwischen den Geschlechtern bei der politischen Rekrutierung - eine weitere Herausforderung für die Demokratisierung der Türkei', in Hoecker, Beate; Fuchs, Gesine (Hrsg.) Handbuch Politische Partizipation von Frauen in Europa II, Die Beitrittsstatten zur Europäischen Union, Opladen, Leske und Budrich.

Atalay, Ahmet (1997) I. ve II. Dönem TBMM Konya Milletvekilleri (Biyografik bir Deneme), Yüksek Lisans tezi, Sosyal Bilimler Enstitüsü, Selçuk Üniv., Doç. Dr. Nuri Köstüklü, 478 p.

Avcı, Cemal (1999) III. Türkiye Büyük Millet Meclisi'nin Yapısı ve Çalışmaları (1927-1931) - The Functions and the Structure of the Third Turkish Grand National Assembly, Doktora Tezi, Sosyal Bilimler Enstitüsü, Ankara Üniv., Pr. Dr. Azmi Süslü, 253 p.

Aybay, Rona (1976) 'Yasama Meclislerinin İçtüzükleri', in Türk Parlamentoculuğunun Illk Yüzyll, Ankara, Ajans-Türk Gazetecilik ve Matbaacılık Sanayii, pp. 283-326.

Bakırcı, Sarı (2000) TBMM'nin Çalışma Yöntemi, Ankara, İmge.

Beldağ, Adam (2003) Sosyal Bilgiler Dersinde TBMM'nin Açılışı Konusunun Öğrencilerdeki Demokratik Bilincin Oluşmasında Etkisi - The Effect of the Opening of the Turkish Grand National Assembly in Social Sciences Lesson on the Formation of the Democratic Consciousness in Students (A Sample Study Located in Town Aşkale Erzurum), Yüksek Lisans Tezi, Sosyal Bilimler Enstitüsü, Atatürk Üniv., Yrd. Doç. Dr. İhsan Sabri Balkaya, 123 p.

Berksü, Heves (2000) Symbolic Masculine and Feminine Identities in Turkish Grand National Assembly, Yüksek Lisans Tezi, Sosyal Bilimler Enstitüsü, Orta Doğu Teknik Üniversitesi, Pr. Dr. Ayşe Ayata, $121 \mathrm{p}$.

Bildirici, Faruk (2000) Siluetini Sevdiğimin Türkiye, Istanbul, Doğan. 
Citation: Dorronsoro, Gilles and Massicard, Elise (2005) 'Being a Member of Parliament in contemporary Turkey', European Journal of Turkish Studies, Thematic Issue $N^{\circ} 3$, Being a MP in contemporary Turkey, URL: http://www.ejts.org/document502.html.

To quote a passage, use paragraph (§).

Bora, Tanıl (2000) 'Professional Chambers and Non-Voluntary Organizations in Turkey: The Intersection of Public, Civil and National', in Yerasimos, Stefanos; Seufert, Günther; Vorhoff, Karin (eds.), Civil Society in the Grip of Nationalism, Istanbul, IFEA- Orient Institut, pp. 99-142.

Bulut, Yakup (1998) '21. Yüzyıla Girerken Türkiye'de Parlamentonun Yasa Faaliyeti, Sorunları ve Çözüm Önerileri', Yeni Türkiye 23-24, pp. 947-958.

Cizre, Ümit (1999) Muktedirlerin Siyaseti, Merkez Sağ - Ordu - İslamcllık, Istanbul, İletişim.

Coşkun, Süleyman (1995) Türkiye'de Politika (1920-1995), Istanbul, Cem.

Cumhuriyet (1977) Seçim 1977, Istanbul, Altın Kitaplar.

Çakan, Işıl (1999) Türk Parlamento Tarihinde II. Meclis, Ankara, Çağdaş.

Devereux, Robert (1963) The First Ottoman Constitutional Period, Baltimore, John Hopkins Press.

Erder, Sema (1996) İstanbul'a bir Kent Kondu - Ümraniye, Istanbul, Iletişim.

Erten, Emre (1996) Türkiye'de Temsil Anlayışı ve Milletvekillerinin Parti Değiştirmesi - The Understanding of Representation in Turkey and the Transfers of the Members of Parliament, Yüksek Lisans Tezi, Sosyal Bilimler Enstitüsü, Dokuz Eylül Üniv., Doç. Dr. Zerrin Toprak Karaman, 111 p.

Esgün, İbrahim Uğur (1998) Türkiye Büyük Millet Meclisi Üyeliğinin Sona Ermesi -The Ending of Membership of the Grand National Assembly of Turkey, Yüksek Lisans Tezi, Sosyal Bilimler Enstitüsü, Ankara Üniv., Pr. Dr. Cem Eroğlu, 136 p.

European Commission (2002) Candidate Countries Eurobarometer: Public Opinion in the Countries Applying for European Union Membership, Brussels.

Ezherli, Ihsan (1998) Türkiye Büyük Millet Meclisi (1920-1998) ve Osmanlı Meclisi Mebusanı (18771920), Ankara, TBMM Kültür, Sanat ve Yayın Kurulu Yayınları, no 54, genişletilmiş 2. baskı.

Fliche, Benoit (2005) 'De l'action réticulaire à la recherche du semblable, ou comment faire lien avec l'administration en Turquie', in Dorronsoro, Gilles (dir.) La Turquie conteste. Régime sécuritaire et mobilisations sociales, Paris, Editions du CNRS, pp. 147-166.

Frey, Frederick W. (1965) The Turkish Political Elite, Cambridge, The M.I.T. Press.

Gençkaya, Ömer Faruk (1990) The Impact of Organizational Attributes on Legislative Performance: A Structural-Functional Analysis of the Grand National Assembly of Turkey, Istanbul, Boğaziçi University, Basılmamış Doktora Tezi.

Gençkaya, Ömer Faruk (1994) 'Democratization and Legislative Development in the Middle East: the Case of Turkey', in Shikara, A. A. R.; Gençkaya, Ömer Faruk, Democratization in the Middle East, Tokyo, IDE.

Gençkaya, Ömer Faruk (1999) 'Reforming Parliamentary Procedure in Turkey', in Keleş, Ruşen; Hazama, Yasushi; Gençkaya, Ömer Faruk (1999) Aspects of Democratization in Turkey, Tokyo, Institute of Developing Economies, JETRO, pp. 2-21.

Göle, Nilüfer (1990) 'Ingénieurs islamistes et étudiantes voilées en Turquie', in Kepel, Gilles ; Richard, Yann (eds.) Intellectuels et militants de l'Islam contemporain, Seuil, Paris. 
Citation: Dorronsoro, Gilles and Massicard, Elise (2005) 'Being a Member of Parliament in contemporary Turkey', European Journal of Turkish Studies, Thematic Issue $\mathrm{N}^{\circ} 3$, Being a MP in contemporary Turkey, URL: http://www.ejts.org/document502.html.

To quote a passage, use paragraph (§).

Güneş-Ayata, Ayşe (1990) 'Class and Clientelism in the Republican People's Party', in Sirman, Nükhet; Finkel, Andrew (eds.), Turkish State, Turkish Society, London, Routledge, pp. 159-184.

Güneş-Ayata, Ayşe (1994) 'Roots and Trends of Clientelism in Turkey', in Güneş-Ayata, Ayşe; Roniger, Luis (eds.), Democracy, Clientelism and Civil Society, Boulder (Colorado), Rienner, pp. 5163.

Hazama, Yasushi (1992) 'The politics of amendment in the Turkish legislatures', The Developing Economies 30, pp. 284-98.

Heper, Metin; Çınar, Menderes (1996) 'Dilemnas of parliamentarianism with a strong presidency: the post-1980 Turkish experience', Political Science Quarterly 111(3), pp. 483-503.

İba, Şeref (1997) Parlamenter Denetim, Ankara, Bilgi.

İçe, Ayşen (2002) Kadın Milletvekilleri ve Siyasal Faaliyetleri (1935-1991) - Women Deputies and their Political Activities (1935-1991), Yüksek Lisans Tezi, Atatürk Illkeleri ve İnkılap Tarihi Enstitüsü, Hacettepe Üniv., Doç. Dr. Mustafa Yılmaz, 132 p.

İnsel, Ahmet; Bayramoğlu, Ali (eds.) (2004) Bir Zümre, Bir Parti: Türkiye'de Ordu. Istanbul, Birikim.

Kalaycıoğlu, Ersin (1980) 'Why legislatures persist in developing countries: the case of Turkey', Legislative Studies Quarterly 5, pp. 123-140.

Kalaycıoğlu, Ersin (1988) 'The 1983 Parliament in Turkey: Changes and Continuities', in Heper, Metin; Evin, Ahmet (eds.), State, Democracy and the Military, Turkey in the 1980s, Berlin- New York, Walter de Gruyter, pp. 51-60.

Kalaycıoğlu, Ersin (1989) 'Cyclical Breakdown, Redesign and Nascent Institutionalization: the Turkish Grand National Assembly', in Liebert, Ulrike; Cotta, Maurizio (eds.), Parliament and Democratic Consolidation in Southern Europe: Greece, Italy, Portugal, Spain and Turkey, London, New York, Pinter Publishers.

Kalaycıoğlu, Ersin (1995) 'The Turkish Grand National Assembly: A Brief Inquiry into the Politics of Representation in Turkey', in Balım, Çiğdem; Kalaycıoğlu, Ersin; Karataş, Cevat; Winrow, Gareth; Yasamee, Feroz (eds.), Turkey: Political, Social and Economic Challenges in the 1990s, Leiden, Brill, pp. 42-60.

Kalaycıoğlu, Ersin (1999) 'Türkiye'de Siyasal Rejimin Evrimi ve Yasama Sistemi' in Rona, Zeynep (ed.), Bilanço 1923-1998: Türkiye Cumhuriyeti'nin 75 Yılına Toplu Bakış Uluslararası Kongresi, I. Cilt: Siyaset - Kültür - Uluslararası Ilişskiler, Istanbul, Tarih Vakfi, pp. 95-110.

Kelleci, Fatmagül (1999) Milletvekillerinin Kişilik Özelliklerini Etkileyen Bazı Dış Etmenlerin Incelenmesi - A Research on some External Effects which Affect the Personality of Deputies, Yüksek Lisans Tezi, Sosyal Bilimler Enstitüsü, 19 Mayıs Üniv., Pr. Dr. Kurtman Ersanlı, 119 p.

Kızır, İsmail (2002) Les origines socio-professionnelles des élites politiques turques : les élus de 1983-1999, Mémoire de fin d'études, université de Galatasaray.

Kumaş, Rahmi (1985) Parlamentonun Boyutları, Ankara, Çağdaş.

Kurmuş, Ömer Saim (1996) Türkiye Büyük Millet Meclisi'nde I. Dönem Bursa Milletvekilleri, Yüksek Lisans tezi, Sosyal Bilimler Enstitüsü, Uludağ Univ., Yrd. Doç. Dr. Sezai Sevim, 198 p. 
Citation: Dorronsoro, Gilles and Massicard, Elise (2005) 'Being a Member of Parliament in contemporary Turkey', European Journal of Turkish Studies, Thematic Issue $N^{\circ} 3$, Being a MP in contemporary Turkey, URL: http://www.ejts.org/document502.html.

To quote a passage, use paragraph (§).

Kutluoğlu, Tamer (1995) Birinci Dönem T.B.M.M.'nde Hasan Fehmi (Ataç) Bey'in Faaliyetleri Activities of Hasan Fehmi Ataç'in the First Term of the National Grand Assembly, Yüksek Lisans tezi, Sosyal Bilimler Enstitüsü, Atatürk Üniv., Yrd. Doç. Dr. Günay Çağlar, 150 p.

Kurtoğlu, Ayça (2004) Hemşehrilik ve Şehirde Siyaset: Keçiören Örneği, Istanbul, Illetişim.

Küçük, Mehmet Yılmaz (1997) Anayasa Hukukunda Milletvekili Sorumsuzluğu, Yüksek Lisans tezi, Sosyal Bilimler Enstitüsü, Gazi Üniv., Doç. Dr. Attila Özer, 105 p.

Loewenberg, Gerhard; Kim, Chong Lim (1978) 'Comparing the representativeness of Parliaments', Legislative Studies Quarterly 3(1), pp. 27-49.

Massicard, Elise (2003) Les élections du 3 novembre 2002: un renouveau de la vie politique turque?, Istanbul, Les dossiers de l'IFEA n¹5, URL: http://www.ifeaistanbul.net/publi/dossiers/dossier15.pdf

McCally, Sarah P. (1956) 'Party government in Turkey', The Journals of Politics 18(2), pp. 297-323.

Meeker, Michael (2002) A Nation of Empire. The Ottoman Legacy of Turkish Modernity, Berkeley I Los Angeles / London, University of California Press.

Oksel, Muhteşem (1999) Milletvekili Seçilme Yeterliliği - Election Capacity of Deputy, Yüksek Lisans tezi, Sosyal Bilimler Enstitüsü, Ankara Üniv., Yrd. Doç. Dr. Muharrem Özen, 287 p.

Onar, Erdal (1977) Meclis Araştırması, Ankara, AÜHF.

Onar, Erdal (1990) '1982 Anayasası'nda TBMM'nin Hükümeti Denetleme İşlevi', 6. Milli Egemenlik Sempozyumu, Ankara, TBMM Kültür, Sanat ve Yayın Kurulu Yayınları.

Oran, Nebahat (1997) Antalya Milletvekili Rasih (Kaplan) Bey'in 1. ve 2. Dönem Türkiye Büyük Millet Meclisi'ndeki Siyasi Faaliyetleri - The Political Activites of Rasih (Kaplan) Bey, the Parliamentarian of Antalya in the 1. and 2. Term TBMM, Yüksek Lisans tezi, Sosyal Bilimler Enstitüsü, Atatürk Üniv., Yrd. Doç. Dr. Selami Kılıç, 115 p.

Özbudun, Ergun (1962) Parlamenter Rejimde Parlamentonun Hükümeti Murakabe Vasitaları, Ankara, AÜHF.

Özbudun, Ergun (1978) 'Parliament in the Turkish political system', Journal of South Asian and Middle Eastern Studies 2, pp. 44-73.

Özbudun, Ergun (1981) 'Turkey: the Politics of Clientelism', in Eisenstadt, Shmuel; Lemarchand, René (eds.), Political Clientelism, Patronage and Development, London, Sage, pp. 249-270.

Pérouse, Jean-François (2005) La Turquie en marche, Paris, La Martinière.

Sarıbay, Ali Yaşar (1984) Türkiye'de Modernleşme Din ve Parti Politkası, Istanbul, Alan.

Sarıbay, Ali Yaşar (1994) Siyasal Sosyoloji, Istanbul, Der.

Sarıdoğan, Neşe (2003) 'Meclisin Bağımsız Vekilleri', Nokta, 28 Mart-10 Nisan, pp. 22-23.

Satılmış, Ayşe Pınar (2002) Birinci ve İkinci Dönem Türkiye Büyük Millet Meclisi'nde Kayseri Milletvekilleri (Biyografi ve Faaliyetleri) - Kayseri Deputies in the First and Second Term Turkish Grand National Assembly (Biography and Activities), Yüksek Lisans Tezi, Sosyal Bilimler Enstitüsü, Erciyes Üniv., Doç. Dr. Ramazan Tosun, 207 p. 
Citation: Dorronsoro, Gilles and Massicard, Elise (2005) 'Being a Member of Parliament in contemporary Turkey', European Journal of Turkish Studies, Thematic Issue $N^{\circ} 3$, Being a MP in contemporary Turkey, URL: http://www.ejts.org/document502.html.

To quote a passage, use paragraph (§).

Sayarı, Sabri (1977a) 'Political Patronage in Turkey', in Gellner, Ernest; Waterbury, John (eds.), Patrons and Clients in Mediterranean Societies, Londres, Duckworth, pp. 103-113.

Sayarı, Sabri (1977b) Parlamenter Demokrasilerde Koalisyon Hükümetleri, İstanbul, Boğaziçi Üniversitesi Yayınları, pp. 167-249.

Schüler, Harald (1998) Die türkischen Parteien und ihre Mitglieder, Hamburg, Deutsches OrientInstitut.

Sümer, Gülizar Çakır (1999) Türkiye'de Kadın Milletvekilleri: 1935-1991, Yüksek Lisans tezi, Sosyal Bilimler Enstitüsü, İnönü Üniv., Metin Kırımhan, 131 p.

Şavkılı Cengiz (2000) Birinci Dönem Türkiye Büyük Millet Meclisi'nde Antep ve Maraş Milletvekilleri (Biyografileri ve Faaliyetleri) - First Period Antep and Maraş Deputies in Turkish Grand National Assembly (their Biographies and Activities), Yüksek Lisans tezi, Sosyal Bilimler Enstitüsü, Erciyes Üniv., Doç. Dr. Ramazan Tosun, 223 p.

Tachau, Frank (1980) 'Parliamentary Elites: Turkey', in Landau, Jacob. M.; Özbudun, Ergun; Tachau, Frank (eds.), Electoral Politics in the Middle East: Issues, Voters and Elites, London, Cromm Helm; Stanford, Hoover, pp. 205-242.

Taştan, Murat (1993) Türkiye Büyük Millet Meclisi'nde Kadın Milletvekilleri, Yüksek Lisans tezi, Türkiyat Araştırmaları Enstitüsü, Marmara Üniv., Yrd. Doç. Dr. Jale Sarmaşık, 163 p.

TBMM Ad Defterleri, TBMM MatbaasI.

TBMM Albümü, 23 Nisan 1920 - 20 Ekim 1991, TBMM Genel Sekreterliği Yayınları no 1, Ankara, 1994.

Teziç, Erdoğan (1980) Türk Parlamento Hukukunun Kaynakları ve ilgili Mahkeme Kararları, İstanbul, Fakülteler Matbaası.

Tuncer, Erol (1996) 24 Aralık 1995 Milletvekili Genel Seçimi/Sayısal ve Siyasal Değerlendirme, Ankara, TESAV.

Tuncer, Erol (1999) 18 Nisan 1999 Milletvekili Seçimleri / Sayısal ve Siyasal Değerlendirme, Ankara, TESAV

Tuncer, Erol (2002) Osmanlı'dan Günümüze Seçimler, 1877-1999, Ankara, TESAV.

Tuncer, Erol; Danacı, Necati (2003) Çok Partili Dönemde Seçimler ve Seçim Sistemleri, Ankara, TESAV.

Tuncer, Erol; Kasapbaş, Coşkun (2003) Seçim 2002 - 3 Kasım 2002 Milletvekili Genel Seçimleri / Sayısal ve Siyasal Değerlendirme, Ankara, TESAV.

Turan, IIIter (1979) 'Parlamenter Demokraside Denetim İşlevi ve Türkiye' Ankara Üniversitesi Siyasal Bilgiler Fakültesi Dergisi 33, pp. 1-35.

Turan, Ilter (1985) 'Changing horse in the midstream: party changes in the Turkish National Assembly', Legislative Studies Quarterly 10, pp. 21-34.

Turan, IIter (1994) 'The Turkish Legislature: From Symbolic to Substantive Representation,' in Copeland, Gary W.; Patterson, Samuel C. (eds.), Parliaments in the Modern World, Changing Institutions, Ann Arbor, the University of Michigan Press, pp. 105-28. 
Citation: Dorronsoro, Gilles and Massicard, Elise (2005) 'Being a Member of Parliament in contemporary Turkey', European Journal of Turkish Studies, Thematic Issue $N^{\circ} 3$, Being a MP in contemporary Turkey, URL: http://www.ejts.org/document502.html.

To quote a passage, use paragraph (§).

Turhan, Mehmet (1991) Siyasal Elitler, Ankara, Gündoğan.

Türk, Hikmet Sami (1997) Seçim Hukukunun Temel Sorunları ve Çözüm Önerileri, Ankara, TESAV.

Türk, Hikmet Sami; Tuncer, Erol (1995) Türkiye İçin Nasıl Bir Seçim Sistemi?, Ankara, TESAV.

Türk Parlamento Tarihi Araştırma Grubu (1996) Türk Parlamento Tarihi, TBMM- II. Dönem, 19231927, II. Cilt, Ankara.

Türk Parlamenterler Birliği (2000) Türkiye'de Siyasal Yapılanma ve Temel Siyasi Sorunlar Sempozyum, Ankara, TESAV.

Türker, Yıldırım (1998) Türkiye Sizinle Gurur Duyuyor, Türk Siyaset Kültüründen Portreler, Istanbul, Metis.

Unbehaun, Horst (1994) Klientelismus in der Türkei, der Kreis Daţa (1923-1992), Hamburg, Deutsches Orient-Institut.

Ünsal, Artun (1982) 'Origines professionnelles des élites politiques turques : les élus de 1977', in Seha L. Meray'a Armağan, Ankara, SBF, pp. 643-678.

Yalçın, Emruhan (1995) Birinci Dönem Erzurum Mebusu Mustafa Durak (Sakarya)'ın Hayatı ve TBMM'deki Faaliyetleri, Doktora Tezi, Atatürk İlkeleri ve İnkılap Tarihi Enstitüsü, Ankara Üniv., Doç. Dr. Dündar Aydın, 509 p.

Yalçın-Heckmann, Lâle (1990) 'Kurdish Tribal Organisation and Local Political Processes', in Sirman, Nükhet; Finkel, Andrew (eds.), Turkish State, Turkish Society, London, Routledge, pp. 289-312.

Yaşar, Yusuf (1997) Milletvekili Sorumsuzluğu ve Dokunulmazlığı, Yüksek Lisans Tezi, Sosyal Bilimler Enstitüsü, Marmara Üniv., Pr. Dr. Emin Artuk, 188 p.

Yılmaz, Gülten (2000) Konya Mebusu Musa Kazım (Onar)'ın 1. Dönem Türkiye Büyük Millet Meclisindeki Faaliyetleri - The Activities of Konya Minister Musa Kazım in the 1. Türkish Grand National Assembly, Yüksek Lisans Tezi, Sosyal Bilimler Enstitüsü, Atatürk Üniv., Yrd. Doç. Dr. Betül Aslan, $158 \mathrm{p}$.

Yücekok, Ahmet N. (1983) Türkiye'de Parlamentonun Evrimi, Ankara, SBF.

Yücel, Sadettin (2002) I. TBMM'nde Dahiliye Vekaleti -The Interior Ministry in the First Turkish Great National Assembly, Yüksek Lisans tezi, Sosyal Bilimler Enstitüsü, 19 Mayıs Üniv., Yrd. Doç. Dr. Kaya Tuncer Çağlayan, $347 \mathrm{p}$.

$\underline{\text { Dergiler }}$

Parlamento

TBMM Aylık Bülten

Memoirs of MPS

Ağaoğlu, Samet (1969) Babamın Arkadaşları, Istanbul, Baha. 
Citation: Dorronsoro, Gilles and Massicard, Elise (2005) 'Being a Member of Parliament in contemporary Turkey', European Journal of Turkish Studies, Thematic Issue $N^{\circ} 3$, Being a MP in contemporary Turkey, URL: http://www.ejts.org/document502.html.

To quote a passage, use paragraph (§).

Burçak, Rıfkı Salim (1976) Yassıada ve Öncesi, Ankara, Çam.

Kirişçioğlu, Nusret (1968) Kayseri Cezaevinde bir Yıldönümü, Istanbul, Baha.

Kocaoğlu, Emre (2003) Sözüm Meclisten İ̧eri: Acemi Milletvekilinin Ankara Anıları, Istanbul, İyiadam.

Perin, Mithat (1990) Yassiada Faciası, 2 vol., Dem. 